\title{
Studies on the nutrition of marine flatfish. Utilization of various dietary proteins by plaice (Pleuronectes platessa)
}

\author{
BY C. B. COWEY, J. ADRON AND A. BLAIR \\ Institute of Marine Biochemistry, St Fittick's Road, Aberdeen ABI ${ }_{3} R A$ \\ AND ALLEN M. SHANKS \\ Marine Laboratory, Victoria Road, Aberdeen AB9 $8 D B$
}

(Received I4 May 1973 - Accepted 8 Nowember 1973)

\begin{abstract}
I. Five proteins, freeze-dried cod muscle, a white fish meal, a yeast-protein concentrate, a soya protein and a fish-protein concentrate (a solvent-extracted fish meal) were given separately, as single sources of protein in diets containing $500 \mathrm{~g}$ crude protein $/ \mathrm{kg}$, to small plaice (Pleuronectes platessa) of mean initial weight I2-I5g. Weight gain and net protein utilization (NPU) were examined.

2. Even at these high protein intakes, significant differences in growth rate between fish given the different proteins were evident. These findings were reflected in different NPU values between the proteins. This position contrasts with that in the rat where proteins which differ markedly in NPU at low protein intakes have similar NPU values when given at high dietary levels.

3. Coefficients of apparent digestibility measured on larger plaice (150-200g) were high for all the proteins used except soya-bean meal, which had a digestibility coefficient of 0.68 .

4. At high protein intakes there was no clear relationship between NPU values and essential amino acid content (as measured chemically) of the proteins tested.

5. The preparation of protein concentrates from fatty fish by the use of detergents is described. One of the preparations obtained gave weight gains and NPU values similar to those obtained with commercially available fecdstuff proteins.
\end{abstract}

Net protein utilization (NPU) by mammals decreases with increasing dietary protein level, progressively more of the protein being used as an energy source as protein intake increases. NPU values for proteins of high and low nutritional quality differ widely at low protein intakes when the amino acid composition of the protein under test is the limiting feature, but are very similar at high protein intakes (Miller \& Payne, rg6r), presumably because the essential amino acid requirements of the animal are met even by proteins of low nutritional quality, provided a sufficient amount of the protein is ingested. Thus, studies on mammals indicate that the quantities of essential amino acids required for optimal growth remain constant provided measurements are made at, or above, the minimum dietary level for optimal growth (Bressani \& Mertz, 1958). Conversely, when expressed as a percentage of protein in the diet, calculated essential amino acid requirements fall as the dietary protein level is increased above the minimum level for optimal growth.

The minimum protein requirement for optimal growth of many fish is high and much of the ingested protein is used as a source of energy, the relationship between NPU and protein intake being similar to that in mammals (Cowey, Pope, Adron \& Blair, 1972). Consequently, unless the quantitative essential amino acid requirements of fish are considerably in excess of those of mammals, it might be expected that at 
these high protein intakes different proteins would not differ greatly in their ability to support growth (i.e. NPU values at this dietary protein level would be similar). In order to examine this possibility, plaice were given several single sources of protein at a high dietary level $(500 \mathrm{~g}$ crude protein/kg diet) and growth rate and NPU were measured. The results obtained indicate that, even at high protein intakes, feedstuff proteins differ in their ability to support the growth of plaice.

In addition, protein concentrates were prepared from two species of fatty fish by the use of surface-active agents. These materials were prepared in an attempt to obtain a low-lipid protein concentrate from fatty fish without the use of organic solvents. They were also tested as sources of dietary protein for plaice at high protein intakes. The results obtained suggest that this type of process could be a useful means of obtaining protein concentrate from trash fatty fish.

\section{EXPERIMENTAL}

\section{Diets}

The composition of the experimental diets is shown in Table $\mathrm{r}$. White fish meal was purchased from Caledonian Fish Meal Co., Aberdeen; promine-D (extracted soya protein) was from Oppenheimer Casing Co. (UK) Ltd, London. Sources of other materials were as described previously (Cowey, Pope, Adron \& Blair, 1971). As BP protein concentrate and promine-D are relatively deficient in methionine, they were supplemented with $10.0 \mathrm{~g} \mathrm{~L}$-methionine $/ \mathrm{kg}$ and $19.0 \mathrm{~g} \mathrm{~L}$-methionine $/ \mathrm{kg}$ respectively before use. Thus the quantity of L-methionine in these two proteins was raised to $3^{\circ} \mathrm{g} / \mathrm{kg}$ crude protein. Promine-D was used in diet 4 rather than the more appropriate commercial feed, soya-bean meal, to permit use of a soya protein alone at a dietary level of $500 \mathrm{~g}$ protein $/ \mathrm{kg}$ diet. All diets contained $500 \mathrm{~g}$ crude protein $/ \mathrm{kg}$ dry diet; the estimated metabolizable energy content per $\mathrm{kg}$ dry diet varied slightly from $15480 \mathrm{~kJ}(3700 \mathrm{kcal})$ in diet 5 , to $17570 \mathrm{~kJ}(4200 \mathrm{kcal})$ in diet 3 . The ratio protein energy: total energy in the different diets varied between 0.68 and 0.77 .

The extracted herring muscle and extracted sprats used in diets 6 and 7 were prepared by extracting these fish with non-ionic, surface-active agents. The procedure applied to herring muscle was: $600 \mathrm{~g}$ herring muscle (previously deep-frozen) were homogenized with $\mathrm{I} \cdot 21$ water and the homogenate was brought to a temperature of $80^{\circ} ; 3^{6 \mathrm{~g}}$ tergitol $15^{-\mathrm{S}}-7$ (Union Carbide Ltd) were added to the homogenate, which was held at $80^{\circ}$ with constant stirring for $\mathrm{I}$ h. The homogenate was then centrifuged $(5000 \mathrm{~g}, 20 \mathrm{~min})$ in polypropylene buckets while still hot. The supernatant fraction was discarded and the precipitate resuspended in I 1 water; this suspension was heated to $80^{\circ}, 3 \circ \mathrm{g}$ tergitol were added and the suspension was again held at $80^{\circ}$ for $\mathrm{I} \mathrm{h}$ with constant stirring. It was then centrifuged, the supernatant fraction discarded and the precipitate suspended in water. The suspended precipitate was transferred to a large Buchner funnel and washed well with water to remove any remaining tergitol. Finally the precipitate was dried in a forced-draught oven at $40^{\circ}$; the yield was $98 \mathrm{~g}$ and the composition of the product is shown in Table 2. Recovery of protein was about $75 \%$, and the lipid content of the material was reduced from $43 \mathrm{~g}$ at the start to $4 \mathrm{~g}$. 
Table I. Composition of experimental diets $(\mathrm{g} / \mathrm{kg}$ dry diet $)$

\begin{tabular}{|c|c|c|c|c|c|c|c|}
\hline \multirow[b]{2}{*}{ Ingredient } & \multicolumn{7}{|c|}{ Diet } \\
\hline & $\mathbf{I}$ & 2 & 3 & 4 & 5 & 6 & 7 \\
\hline Freeze-dried cod muscle & 575 & 一 & - & - & - & -- & - \\
\hline White fish meal & & 715 & - & - & - & - & - \\
\hline BP protein concentrate* & - & - & 830 & - & - & - & - \\
\hline Promine- $\mathrm{D}^{*}$ & - & - & - & 545 & - & - & - \\
\hline A fish-protein concentrate & - & - & - & - & 620 & $\ldots$ & - \\
\hline Extracted herring muscle & - & - & - & - & - & 563 & - \\
\hline Extracted sprats & - & - & - & - & - & - & 602 \\
\hline$\alpha$-Cellulose & 265 & 125 & 10 & 295 & 220 & 227 & 238 \\
\hline Additional components $\dagger$ & 160 & 160 & 160 & $x 60$ & 160 & 160 & 160 \\
\hline
\end{tabular}

Table 2. Extraction of $600 \mathrm{~g}$ of herring muscle and of sprats with surface-active agents

\begin{tabular}{|c|c|c|c|c|c|c|}
\hline \multirow[b]{2}{*}{ Material } & \multicolumn{3}{|c|}{$\begin{array}{c}\text { Composition of starting } \\
\text { material }(\mathrm{g})\end{array}$} & \multicolumn{3}{|c|}{ Composition of product ( $\mathrm{g}$} \\
\hline & Water & Protein & Lipid & $\begin{array}{l}\text { 1otal } \\
\text { weight }\end{array}$ & Protein & Lipid \\
\hline Herring muscle & 420 & Ir6 & 43 & 98 & 87 & 4 \\
\hline Sprats & 410 & 102 & 58 & 79 & 65 & $3 \cdot 5$ \\
\hline
\end{tabular}

A similar procedure was applied to sprats, except that Tween 80 (polyoxyethylene sorbitan mono-oleate; Sigma Chemical Co. Ltd, London) was used at a concentration of $20 \mathrm{~g} / \mathrm{l}$ instead of tergitol. The composition of the product is shown in Table 2.

In addition to the diets listed in Table I, a low-protein diet was given to a further group of fish, thus permitting evaluation of NPU of the proteins under examination as described previously (Cowey et al. 1972). Values for growth obtained with this diet were not included in the analysis of weight gains.

The digestibility of the different proteins was determined by a ratio method using an inert indicator (Furukawa \& Tsukahara, 1966; Knapka, Barth, Brown \& Cragle, I967). Fish of $150-200 \mathrm{~g}$ live weight were given diets containing $5 \mathrm{~g}$ chromic oxide per $\mathrm{kg}$ of the protein under test for $2-3$ weeks; they were then lightly anaesthetized by immersion in sea-water containing I part of M.S. 222 ( $m$-ethoxycarbonylanilinium methanesulphonate; Sandoz Products Ltd, London) in 10000 . After removal from the sea-water, gentle finger pressure was applied to the surfaces of the fish in the rectal region and the faecal material so expelled was collected in a petri dish. This material was dried at $100^{\circ}$ before its nitrogen and chromic oxide contents were measured.

\section{Animals and tank system}

Young plaice (Pleuronectes platessa), about 9 months old, were obtained from the White Fish Authority Marine Fish Cultivation Unit, Hunterston, Ayrshire, where they had been fed on a diet of minced, trash fish. The plaice were distributed 
between seven tanks $(\mathrm{r} .9 \times 0.84 \times 0.6 \mathrm{r}$ deep $)$ standing along one wall of a rectangular room; each tank contained sea-water to a depth of $0.35 \mathrm{~m}$. Light was provided only from fluorescent tubes which gave an intensity of $60 \mathrm{~lx}$ at the water surface in cach tank. Sea-water flowed by gravity through the fish tanks at a rate of $601 / \mathrm{h}$ per tank from a 100001 reservoir situated in the rectangular room adjacent to that containing the fish tanks. From the fish tanks, water flowed through a biological filter (where oxidation of ammonia, excreted by the fish, to nitrate occurred) to a sump from where it was pumped back to the reservoir through an ultraviolet sterilizer (Hanovia Model 6, Nafloc Ltd, Northwich, Cheshire). The biological filter, sump, u.v. light and pumps were housed in a separate rectangular room adjacent to the fish tank room and distant from the reservoir room. Sea-water was discarded from the reservoir at weekly intervals and replaced by fresh sea-water. Ammonia levels in the water were monitored regularly (not less than once per week) and never exceeded $0.2 \mathrm{mg} / \mathrm{l}$. All three rooms were thermally insulated and both air and water temperatures controlled at $\mathrm{I}_{5} \pm 2^{\circ}$.

Fish werc first accustomed to an artificial diet (diet 4 of Cowey et al. 1972). Some fish were then discarded from each tank and small number of others re-allocated between the seven tanks in such a way as to provide in each tank approximately equal numbers of individuals, a similar total biomass, and a similar size distribution. The fish in each tank were then marked by subdermal injection of differently coloured rubber latex dyes (Riley, $19^{6} 5_{5}$ ) on the ventral surface so that they were individually identifiable.

After 2-3 weeks on this diet, fish were given the seven experimental diets (Table 1 ) for $3 \mathrm{~d}$, all the fish within the same tank receiving the same diet. All the diets were readily accepted by the fish, so initial weight measurements were made and the experiment was begun. All the fish were removed from each experimental tank and transferred to separate, small, portabie tanks, one for each treatment. From each of the portable tanks in turn fish were removed singly with a hand net, drained for $10 \mathrm{~s}$ during which time the colour code was identified, and placed on a piece of rigidlybacked, water-absorbent sponge. The weight of sponge + fish was rapidly determined on a Mettler $P$ I 200 top-pan balance and the fish was put into another small, portable tank. The wcight of the sponge (plus any water it had absorbed) was then determined. When all the individuals on any treatment had been weighed they were returned to one of the experimental tanks. This method of weighing proved satisfactory and reproducible. Fish were not fed for $\mathrm{I} 8 \mathrm{~h}$ before weighing. Feeding procedure was as described previously (Cowey et al. 1972).

With the resources available it was not possible to replicate the tanks allotted to each diet. Experience with this tank system has shown, however, that groups of fish of a similar size kept in separate, identical tanks and given the same diet do not differ in growth rate. Moreover, at each bi-weekly weighing, fish were returned to a different experimental tank from that in which they had spent the previous fortnight.

At the start of the experiment there were twenty to twenty-two individuals in each tank. No mortalities occurred during the experiment. A small number of fish given some of the diets showed abnormally large or small growth, and values for them were excluded from the analysis of weight gains, but were included in the measurement of 


\section{Table 3. Initial weights $(g)$ of experimental plaice}

\begin{tabular}{|c|c|c|c|c|c|}
\hline \multirow[b]{2}{*}{$\begin{array}{c}\text { Diet } \\
\text { no. }\end{array}$} & \multirow{2}{*}{$\begin{array}{l}\text { No. of } \\
\text { fish }\end{array}$} & \multicolumn{3}{|c|}{ Distribution of initial wt } & \multirow[b]{2}{*}{ Mean initial wt } \\
\hline & & $<$ IO & $10-<20$ & $\geqslant 20$ & \\
\hline I & I6 & 4 & I I & $\mathbf{I}$ & $12 \cdot 65$ \\
\hline 2 & 22 & 7 & 12 & 3 & $13 \cdot 52$ \\
\hline 3 & $2 I$ & 5 & 10 & 6 & 14.98 \\
\hline 4 & 17 & 5 & 9 & 3 & 13.48 \\
\hline 5 & $2 \mathrm{I}$ & 9 & 9 & 3 & $13 \cdot 36$ \\
\hline 6 & $2 I$ & 7 & 12 & 2 & $13 \cdot 39$ \\
\hline 7 & I9 & 8 & 8 & 3 & 14.11 \\
\hline
\end{tabular}

Table 4. Mean weights $(g)$ of plaice at successive fortnightly intervals

\begin{tabular}{|c|c|c|c|c|c|c|c|}
\hline \multirow{2}{*}{$\begin{array}{c}\text { Diet } \\
\text { no. }\end{array}$} & \multicolumn{6}{|c|}{ Wt after weeks } & \multirow{2}{*}{$\begin{array}{l}\text { Average } \\
\text { wt gain after } \\
\text { Io weeks }\end{array}$} \\
\hline & 0 & 2 & 4 & 6 & 8 & IO & \\
\hline$x$ & $12 \cdot 65$ & 14.62 & 1752 & 19.79 & 2473 & $29^{\circ} 47$ & $16 \cdot 82$ \\
\hline 2 & 13.52 & $15 \cdot 32$ & $17 \cdot 48$ & I9'I 4 & $22 \cdot 32$ & 25.80 & 12.28 \\
\hline 3 & I 4.98 & 16.75 & I $9.5^{8}$ & 20.92 & $23 \cdot 44$ & $25 \cdot 13$ & I0. 16 \\
\hline 4 & I 3.48 & I $4.3^{8}$ & 16.55 & $17 \cdot 63$ & 19.72 & 20.99 & 7.52 \\
\hline 5 & I $3 \cdot 36$ & 14.73 & 16.98 & $17 \cdot 23$ & 19.87 & $20.2 \mathrm{I}$ & 6.85 \\
\hline 6 & 13.39 & I 5.45 & I $7 \cdot 2 \mathrm{I}$ & $18 \cdot 75$ & 20.41 & 20.79 & $7 \cdot 40$ \\
\hline 7 & I4. I I & 15.70 & $17.5^{2}$ & $19.2 I$ & $21 \cdot 4^{8}$ & $23 \cdot 36$ & $9 \cdot 26$ \\
\hline
\end{tabular}

NPU. Table 3 gives the number of fish used in the analysis of growth, the distribution of their initial weights, and the mean initial weight for each diet.

\section{RESULTS}

The average bi-weekly weights and the average total growth of fish given each diet are shown in Table 4; they show that the highest average weight gain was produced by diet $\mathrm{I}$. Within treatments, it appeared that gain in weight over the experimental period was linearly related to initial weight. To take account of this association, linear regressions of weight gain on initial weight were calculated for each diet. Although there was evidence that the relationship between weight gain and initial weight was more marked for some diets than others, a common slope was calculated for all diets. That is, it was assumed that the difference in total weight gain corresponding to any given difference in initial weight was the same for all diets. The relationships for each diet were:

$$
\begin{aligned}
& \operatorname{diet} \mathrm{I}, Y=12.744+0.3221 X \\
& \operatorname{diet} 2, Y=7.926+0.3221 X \\
& \operatorname{diet} 3, Y=5.333+0.3221 X \\
& \operatorname{diet} 4, Y=3.177+0.322 \mathrm{I} X \\
& \operatorname{diet} 5, Y=2.550+0.3221 X \\
& \operatorname{diet} 6, Y=3.093+0.3221 X \\
& \operatorname{diet} 7, Y=4.715+0.3221 X
\end{aligned}
$$

$Y$ is the gain in weight $(\mathrm{g})$ and $X$ is the initial weight $(\mathrm{g})$. 
Table 5. Estimated average weight gains ( $g$ ) after Io weeks, with their standard errors, of plaice of $13.7 \mathrm{~g}$ initial weight

$\begin{array}{ccc}\text { Diet } & \begin{array}{c}\text { Estimated gain } \\ \text { in wt }\end{array} & \text { SF } \\ \text { I } & \mathrm{r} 7 \cdot 2 & 0.80 \\ 2 & \mathrm{I2 \cdot 3} & 0.68 \\ 3 & 9 \cdot 7 & 0.70 \\ 4 & 7 \cdot 6 & 0 \cdot 77 \\ 5 & 7 \cdot 0 & 0 \cdot 70 \\ 6 & 7 \cdot 5 & 0.70 \\ 7 & 9 \cdot 1 & 0.73\end{array}$

From these equations, the expected weight gains of fish given different diets were calculated using a value for initial weight of $13.7 \mathrm{~g}$ (the mean initial weight of all the experimental fish) and these are given in Table 5 .

The values in Table 5 show that diet I (freeze-dried cod muscle) clearly promoted much greater growth than any of the other diets. The next-highest average weight was obtained with diet 2 (white fish meal), which was significantly $(P<0.0$ I) better than diets 3 (BP protein concentrate) and 7 (extracted sprats), the difference in expected weight gains between diets 2 and 3 being $2.6 \pm 0.98 \mathrm{~g}$ and between diets 2 and $7,3.2 \pm x \cdot 00 \mathrm{~g}$. Diets 3 and 7 in turn produced higher expected weight gains than diets 4 (promine-D), 5 (fish-protein concentrate) and 6 (extracted herring muscle), which produced the poorest gains of all the diets and were not themselves significantly different.

The interesting feature of these results is the poor growth rate of fish given diet 5 containing, as sole source of protein, a fish-protein concentrate obtained by solvent extraction of fish meal. The growth rate of fish given this diet is significantly less than, and contrasts markedly with, that of animals given other fish proteins (diets $x$ and 2). It is noteworthy (Table 6) that the fish given diet 5 consumed more protein than did either of the groups given diets I or 2 . It must be deduced, therefore, that there are real differences in nutritional value between this fish-protein concentrate and the other two proteins derived from fish (freeze-dried cod muscle and white fish meal).

Results of measurements of protein quality of the diets appear in Table 6. NPU values for diets $I, 2,3$ and 4 were somewhat similar, indicating that at the dietary protein level used there was little difference in their relative nutritional value. Diet 5 , on the other hand, gave a much lower NPU value than most other diets, especially diets I-4. The absence of a facility to replicate treatments precluded any assessment of the significance of differences in NPU but, taken in conjunction with the findings on weight gain, real differences seem to exist in relative nutritional value of the fishprotein concentrate and the other proteins derived from fish (diets $I$ and 2). The detergent-extracted fatty fish (dicts 6 and 7 ) were not markedly inferior to the best of the commercial proteins (diets 2,3 and 4), and to this extent the method used for their extraction is promising.

With the exception of soya-bean meal, the proteins under examination were of 
'Table 6. Total live-weight gains of the plaice and biological evaluations of the proteins

\begin{tabular}{|c|c|c|c|c|c|c|}
\hline \multirow[b]{2}{*}{$\begin{array}{l}\text { Diet } \\
\text { no. }\end{array}$} & & \multirow[b]{2}{*}{$\begin{array}{l}\text { Live-wt } \\
\text { gain } \\
\text { (g) }\end{array}$} & \multirow[b]{2}{*}{$\begin{array}{l}\text { Protein } \\
\text { consumed } \\
(g)\end{array}$} & \multirow[b]{2}{*}{ PER } & \multirow[b]{2}{*}{ NPU } \\
\hline & $\begin{array}{l}\text { Initial } \\
(\mathrm{g})\end{array}$ & $\begin{array}{l}\text { Final } \\
(\mathrm{g})\end{array}$ & & & & \\
\hline I & 2953 & $678 \cdot 4$ & $3^{8} 3_{3} \cdot 1$ & 215 & I. 78 & 0.42 \\
\hline 2 & 297.5 & 5677 & 270.2 & 210 & $1 \cdot 29$ & 0.35 \\
\hline 3 & $297^{\circ} 9$ & $506 \cdot 9$ & 209.0 & $I 7 I$ & $x \cdot 23$ & 0.38 \\
\hline 4 & $298 \cdot 2$ & $420 \cdot 6$ & 122.4 & $\mathrm{I}^{8} 8$ & 0.89 & 0.34 \\
\hline 5 & $290 \cdot 6$ & $43+2$ & 140.6 & 240 & 0.60 & 0.23 \\
\hline 6 & $288 \cdot 5$ & $442 \cdot 5$ & $154^{\circ} \circ$ & 184 & 0.84 & 0.30 \\
\hline 7 & $279 \cdot I$ & $455^{\circ} 2$ & $176 \cdot \mathrm{I}$ & 180 & 0.08 & 0.33 \\
\hline
\end{tabular}

PER, $g$ wt gain per $g$ protein eaten; NTU, $\left[B-\left(B_{k}-I_{k}\right)\right] / I$, where $B$ and $B_{k}$ are the total body nitrogen and $I$ and $I_{k}$ the nitrogen intakes of the fish on the test and low-protein diets respectively.

Table 7. Digestibility, for plaice, of the proteins used

$\begin{array}{lcc}\text { Protein source } & \begin{array}{c}\text { Concentration in } \\ \text { dry diet }(\mathrm{g} / \mathrm{kg})\end{array} & \begin{array}{c}\text { Digestibility } \\ \text { ratio }\end{array} \\ \text { Freeze-dried cod muscle } & 500 & 0.91 \\ \text { Soya-bean meal } & 400 & 0.68 \\ \text { BP protein concentrate } & 500 & 0.90 \\ \text { White fish meal } & 500 & 0.86 \\ \text { A fish-protein concentrate } & 500 & 0.89\end{array}$

uniformly high digestibility (Table 7 ). The digestibility of soya-bean meal was examined because this material, rather than promine-D, might feature in commercial diets. The low apparent digestibility of the protein in soya-bean meal may be due to the relatively high levels of carbohydrate in this material. Promine-D has a high digestibility. We have found that marine flatfish have very limited amylotic activity in their gastrointestinal tract (unpublished), and it has been observed by Kitamikado, Morishita \& Tachino (1964), using rainbow trout (Salmo gairdnerii), that high dietary starch levels have a detrimental effect on the digestibility of protein.

The measurements of apparent digestibility were made on fish weighing I 50-200 g, that is, considerably larger animals than those on which the weight-gain measurements were made (mean initial weights I2 $^{2} 15 \mathrm{~g}$, Table 3 ). Kitamikado et al. (1964) examined the relationship between digestibility and weight of rainbow trout; they found no significant differences in the digestibility of protein (casein, white fish meal) in fish of body-weight 'from about Io $\mathrm{g}$ to roo $\mathrm{g}$ ' but in smaller fish ('less than about $6 \mathrm{~g}$ body-weight') apparent digestibility of these proteins showed considerably lower values. Nevertheless, the possibility that the feedstuffs we used differ in digestibility for small plaice $(12-15 \mathrm{~g})$ cannot be ruled out. It is not easy to apply our method for collection of faeces to small flatfish because the gastrointestinal tract is short and is concentrated in a small peritoneal cavity. There is a likelihood of damage to the fish and the expulsion of material from the mid-gut region, producing spurious results.

The gross composition of fish given the different diets was similar at the end of the experiment, mean values $( \pm \mathrm{SE})$ being $(\mathrm{g} / \mathrm{kg})$ : water $762 \cdot \mathrm{I} \pm 3.03$, protein 
Table 8. Chemically measured essential amino acids* in diets containing the proteins under test at levels of $500 \mathrm{~g}$ crude protein/kg dry diet

\begin{tabular}{|c|c|c|c|c|c|c|}
\hline \multirow[b]{2}{*}{$\begin{array}{l}\text { Amino } \\
\text { acid }\end{array}$} & \multicolumn{5}{|c|}{ Amount in test protein ( $\mathrm{g} / \mathrm{kg} \mathrm{dry}$ diet) } & \multirow[b]{2}{*}{$\begin{array}{l}\text { Essential amino } \\
\text { acid requirement } \\
\text { of Chinook } \\
\text { salmont (g/kg dry } \\
\text { diet) }\end{array}$} \\
\hline & $\begin{array}{l}\text { Freeze- } \\
\text { dried } \\
\text { cod } \\
\text { muscle }\end{array}$ & $\begin{array}{l}\text { White } \\
\text { fish } \\
\text { meal }\end{array}$ & $\begin{array}{l}\text { BP protein } \\
\text { concen- } \\
\text { trate }\end{array}$ & Promine D & $\begin{array}{l}\text { A fish } \\
\text { protein } \\
\text { concen- } \\
\text { trate }\end{array}$ & \\
\hline Lysine & $46 \cdot 0$ & $37 \cdot 9$ & $36 \cdot 0$ & $30 \cdot 3$ & $46 \cdot 5$ & 20 \\
\hline Histidine & II.O & $9 \cdot 9$ & 10.0 & $12 \cdot 3$ & 14.0 & 7 \\
\hline Arginine & $30 \cdot 5$ & $33 \cdot 9$ & $25 \cdot 0$ & $39^{\circ} 0$ & $33^{\circ} \circ$ & 24 \\
\hline Threonine & 22.0 & 18.9 & $26 \cdot 0$ & $18 \cdot 5$ & $26 \cdot 5$ & 9 \\
\hline Valine & 24.0 & $23 \cdot 3$ & $28 \cdot 5$ & $24 \cdot I$ & $29 \cdot 5$ & 13 \\
\hline Methionine & $14 \cdot 5$ & 14.6 & 15.01 & $15 \cdot 07$ & 144 & 16 \\
\hline Isoleucine & 23.5 & 19.4 & 23.5 & $24 \cdot 2$ & 24.5 & 9 \\
\hline Leucine & $37 \cdot 5$ & $32 \cdot 4$ & $36 \cdot 5$ & $38 \cdot 7$ & $4 I \cdot 5$ & 16 \\
\hline Phenylalanine & 20.5 & 174 & 22.0 & $26 \cdot 8$ & $23 \cdot 5$ & $21 \xi$ \\
\hline Tryptophan & $6 \cdot 0$ & 477 & $7 \cdot 0$ & $6 \cdot 7$ & $5^{\circ}$ & 2 \\
\hline Cystine & 5.5 & $3 \cdot 4$ & 5.0 & $5 \cdot 2$ & 5.0 & \\
\hline Tyrosine & $\mathrm{I} 7 \cdot 5$ & $14 \cdot 8$ & $18 \cdot 5$ & $18 \cdot 5$ & 20.5 & \\
\hline
\end{tabular}

I $55^{\circ} \pm 0.74$, lipid $51^{\circ} 0 \pm 2 \cdot 52$ and ash $28 \cdot 7 \pm 0.47$. Lipid was the most variable component, ranging from $43 \mathrm{~g} / \mathrm{kg}$ live weight (dict 6) to $62 \mathrm{~g} / \mathrm{kg}$ live weight (diet 3 ), values considerably higher than those of wild fish (Cowey et al. 1972).

\section{DISCUSSION}

Proteins differ in their ability to support the growth of plaice even when given at high dietary concentrations. Moreover, there is no evidence that these differences are due to differences in digestibility of the proteins concerned. A possible explanation may lie in a high requirement by the fish for one or more essential amino acids coupled with either a relative deficiency or a low biological availability of some essential amino acids in some of the proteins.

Since this paper was submitted, Ogino \& Chen (1973) have reported results somewhat similar to ours but obtained from experiments with carp (Cyprimus carpio). They examined the biological value of four proteins (casein, white fish meal, dried egg yolk and maize-gluten meal) at dietary protein concentrations of between about 100 and $400 \mathrm{~g} / \mathrm{kg}$. The point of interest is that the relationships between biological value and dietary protcin level which they obtained for all four proteins were virtually parallel to each other. Thus, differences in biological value were as evident at high protein intakes as at low protein intakes.

The only values available for quantitative requirements of fish for essential amino acids are those for Chinook salmon (Oncorhynchus tschawytscha) determined by Halver and his colleagues (summarized by Mertz, I969) using diets containing 
$400 \mathrm{~g}$ protein $/ \mathrm{kg}$. These results are shown in Table 8 . Two points are worthy of note; first, the value for phenylalanine is really the requirement for phenylalanine and tyrosine together, it having been shown that with $4 \mathrm{~g}$ tyrosine $/ \mathrm{kg}$ diet the phenylalanine requirement was $17 \mathrm{~g} / \mathrm{kg}$ diet. Secondly, the position regarding methionine requirement is complicated by the sparing action of cystine. With a cystine level of $0.5 \mathrm{~g} / \mathrm{kg}$ diet, Chinook salmon failed to show maximum growth even with $16 \mathrm{~g}$ methionine $/ \mathrm{kg}$ diet. When Io $\mathrm{g}$ cystine/kg diet were present, the methionine requirement appeared to be $5^{-6} \mathrm{~g} / \mathrm{kg}$ diet.

Also shown in Table 8 are the quantities of essential amino acids in the proteins given to plaice in the present experiments. When expressed as a proportion of the diet, the requirements of the fish for most of the essential amino acids are greater than the corresponding requirements of mammals. Nevertheless, when these proteins are given at the high dietary levels required by fish, essential amino acids are apparently supplied considerably in excess of requirement, with the possible exceptions of methionine and phenylalanine, for which there is some difficulty in fixing an exact requirement.

Thus the differences in growth rate of plaice observed here cannot be explained on the basis of the essential amino acid content of the proteins used. This is made especially manifest by a comparison of the growth of fish given diets I and 5 ; chemically measurable quantities of essential amino acids in the two proteins involved are similar, but growth rates and NPU are markedly different at comparable protein intakes. It remains possible that differences may exist in the biological availability of some essential amino acids in the proteins, but this has not yet been shown to be so. Consequently the problem of relating amino acid composition to nutritional value at high protein intakes remains unresolved.

Treatment of fatty fish with surface-active agents gave products which were both acceptable to the test fish (no pathological signs appeared as a consequence of feeding) and more or less similar to commercial feedstuffs in nutritional value. Surface-active agents have been used to obtain a fish-protein concentrate by Caiozzi, Arrieta, Villarroch \& Rauch (1968) and by Connell (1969). The former group used the ionic detergent sodium dodecyl sulphate to extract fat from a full-fat fish meal and were able to reduce the diethyl ether-extractable fat from $46 \mathrm{~g} / \mathrm{kg}$ to $2 \mathrm{~g} / \mathrm{kg}$ by their best procedure. Connell ( 1969 ), on the other hand, used sodium dodecyl sulphate at a concentration of $5 \circ \mathrm{g} / 1$ to solubilize protein from comminuted whole fatty fish; the solubilized protein was then easily separated from the denser skin and bones and the less dense oil. Recovery of the solubilized protein was achieved by the use of either organic solvents (giving a product containing sodium dodecyl sulphate up to $4^{\circ}$ $\mathrm{g} / \mathrm{kg}$ ) or by precipitation at $\mathrm{pH} 3-4$ (giving a product containing up to $400 \mathrm{~g}$ sodium dodecyl sulphate $/ \mathrm{kg}$ ). Connell took the view that the latter product was unacceptable because of its detergent content, and the use of organic solvents to recover solubilized protein offered no advantage in cost over the procedures at present used.

The process used in the present experiment was designed to emulsify fat rather than solubilize protein; even so, considerable amounts of protein were lost and appreciable lipid remained in the product. No attempt was made to measure residual 
detergent in the products but, as the fish ate diets containing high concentrations of them for Io weeks without obvious signs of toxicity, this does not appear to be a particular problem. Since this work was carried out Hikota \& Meguro (rg69) have examined the properties of another group of surface-active agents, alkylsulphoacetates. These are said to be hydrolysed by dilute acid at $40^{\circ}$. Provided their emulsifying power is sufficiently great, these reagents may be of considerable use in the type of process envisaged because their removal from the product ought to be relatively easy. In fact, a readily hydrolyzable, surface-active agent of high emulsifying power could give rise to a useful process for the production of low-fat, high-protein meals from trash fatty fish.

We are grateful to Dr P. T. Grant for his continued interest and helpful suggestions concerning the use of detergents to produce protein concentrates from fatty fish.

\section{REFERENCES}

Bressani, R. \& Mertz, E. T. (1958). F. Nutr. 65, 48r.

Caiozzi, M., Arrieta, L., Villarroch, T. \& Rauch, E. (1968). Fd Technol, Lond. 22, Ioo.

Connell, J. J. (1969). Fd Technol, Lond. 23, 72.

Cowey, C. B., Pope, J. A., Adron, J. W. \& Blair, A. (1971). Mar. Biol. 1o, 145.

Cowey, C. B., Pope, J. A., Adron, J. W. \& Blair, A. (1972). Br. Y. Nutr. 28, 447.

Furukawa, A. \& Tsukahara, H. (r966). Bull. Fap. Sac. scient. Fish. 32, 502.

Hiliota, T. \& Meguro, K. (r960). F. Am. Oil Chem. Soc. 46, 579.

Kitamikado, M., Morishita, T. \& Tachino, S. (1964). Bull. Fap. Soc. scient. Fish. 30, 50.

Knapka, J. J., Barth, K. M., Brown, D. G. \& Cragle, R. G. (1967). F. Nutr. 92, 79.

Mertz, E. T. (1969). In Fish in Research, p. 233 [O. W. Neuhaus and J. E. Halver, editors]. New York: Academic Press.

Miller, D. S. \& Payne, P. R. (196r). Br. F. Nutr. I5, I I.

Ogino, C. \& Chen, M. (1973). Bull. Jap. Soc. scient. Fish. 39, 797.

Riley, J. D. (1965). F. Cons. perm. int. Explor. Mer. 30, 354. 